Institute for Research on Poverty

Discussion Paper no. 1042-94

\title{
Health Insurance and Child Support
}

\author{
Daniel R. Meyer \\ School of Social Work \\ and \\ Institute for Research on Poverty \\ University of Wisconsin-Madison
}

September 1994

This research was supported in part by the U.S. Department of Health and Human Services/Assistant Secretary for Planning and Evaluation through a grant to the Institute for Research on Poverty. Some of the data used in this paper were gathered under a contractual agreement between the Wisconsin Department of Health and Human Services and the Institute for Research on Poverty. Any views expressed in this paper are those of the author and not necessarily those of the sponsoring institutions. I thank Mei-Chen $\mathrm{Hu}$ for her research assistance and Maria Cancian, Irwin Garfinkel, Karl Kronebusch, Linda Mellgren, Janice Peskin, and Barbara Wolfe for comments on an earlier draft. 


\begin{abstract}
The child support system has been increasing its efforts to make health insurance a part of child support awards. Data from the 1990 Current Population Survey-Child Support Supplement show that 40 percent of child support awards require that the noncustodial parent provide health insurance to his children. However, in a third of the cases, the noncustodial parents are not providing coverage. This matters because 16 percent of the children whose noncustodial fathers are not providing the coverage they were ordered to provide are not insured through other sources (e.g., Medicaid). But expecting noncustodial parents to be the sole providers of health insurance for their children may be unwise. Data from Wisconsin suggest that fewer than half (and probably less than 10 percent) of uninsured children in custodial-parent families have a noncustodial parent who can afford to provide health insurance for them. Health care reform is needed so that all children will have coverage, whether it is provided by their parents or the government.
\end{abstract}




\section{Health Insurance and Child Support}

\section{INTRODUCTION}

Many politicians and health care analysts have declared that the health care system is in crisis. The number of uninsured Americans is large and growing, having reached over 37 million in 1993 (U.S. Bureau of the Census, 1993b), and medical costs are skyrocketing, especially public costs. Outlays for Medicare, the program for the elderly and disabled, increased by 122 percent in real terms between 1980 and 1992; the costs of Medicaid, the program for poor seniors, disabled persons, and single-parent families, increased 169 percent during the same period (U.S. House of Representatives, 1993).

One group whose health care coverage has raised concern is children in single-parent families. In part, this concern has arisen because of the dramatic growth in the proportion of children living with one parent only, from 9 percent in 1960 to almost 27 percent in 1992 (U.S. Bureau of the Census, 1993a). Another reason for concern about these children is that their poverty rates are quite high (U.S. Bureau of the Census, 1993b), and the poor are both more likely to have health problems (Kasper, 1986; Wolfe, 1992) and to be uninsured (Moyer, 1989).

Responsibility for providing health care coverage to this group of vulnerable children could be placed on custodial parents (typically mothers), taxpayers (through the Medicaid program), noncustodial parents (typically fathers), or a combination thereof. Because custodial parents are frequently poor, and because public costs are mounting, requiring noncustodial parents to provide coverage has seemed an attractive policy option.

Several changes in the child support system have been aimed at increasing the number of noncustodial parents who provide coverage for their children. Since 1984, all state child support agencies have been required to request that health insurance coverage be part of child support orders when it is available to the noncustodial parent at a reasonable cost. Initially, cases in which the 
custodial family was already covered by health insurance were exempt; the provisions applied only to families that were uninsured or covered by Medicaid only. Subsequent regulations removed this exemption and also require that coverage be pursued even if it means there may be less cash available for child support. Child support agencies are also supposed to monitor whether insurance is actually provided once it is ordered.

Yet in spite of the interest in such coverage, we know little about the relationship between health insurance and the child support system. This paper presents information on three interrelated areas:

- How frequently is the noncustodial parent required to provide health insurance as part of a child support award? When it is required, is it provided?

- What is the potential for more noncustodial parents to provide coverage for children who are uninsured or who are receiving Medicaid only?

- Are child support cash awards lower when health insurance coverage is included?

Previous research in these three areas is summarized in Section II, data and methods are presented in Section III, and Section IV provides results.

\section{PREVIOUS RESEARCH}

\section{$\underline{\text { Health Insurance Coverage and Child Support Awards }}$}

The extent of health coverage in child support awards can be obtained from the April child support supplement to the 1990 Current Population Survey (CPS-CSS). Of the women with child support awards who were surveyed, 40 percent have health insurance for the children as part of their award (U.S. Bureau of the Census, 1991a). But even if health insurance coverage is part of a child support award, it may not be provided: only 68 percent of the women with health insurance coverage in their award reported it actually being provided by the children's father (U.S. Bureau of the Census, 
1991a). ${ }^{1}$ On the other hand, health insurance may be provided by the father even if it is not in the child support award: 7 percent of the women who have awards that do not include health insurance reported receiving health coverage for their children from the children's father.

Although there has been increased policy attention given to including health insurance in awards, the proportion of women with coverage for their children in their awards has not risen substantially over time. In fact, the percentage with coverage in their awards declined from 46 percent in 1983 to 45 percent in 1985 and 39 percent in 1987 before the slight increase to 40 percent in 1989 (U.S. Bureau of the Census, 1986, 1989, 1990). ${ }^{2}$ Two studies that examined the records of cases in the child support system revealed a more positive situation, showing substantial growth in the percentage with health insurance in awards during the late 1980s (U.S. General Accounting Office, 1992; Gordon, 1991). However, more than three-fourths of the records of cases in which insurance was part of the order did not indicate if the insurance was actually being provided (Gordon, 1991).

In summary, some information is available on whether health insurance is included in child support awards and whether it is provided by the noncustodial parent. But what is not known is whether the children who do not have coverage from the noncustodial parent have private coverage from some other source, are uninsured, or have Medicaid coverage only. Clearly if these children have insurance coverage from another source, the lack of coverage through the noncustodial parent is a less important problem.

\section{The Potential for Increasing Private Coverage through Noncustodial Parents}

Two estimates of the potential for increasing health coverage through insurance provided by noncustodial parents have been completed (Nightingale et al., 1986; U.S. General Accounting Office, 1992). Unfortunately, neither of these studies had information on the noncustodial parent available to them, so both estimates are quite crude. ${ }^{3}$ 
Information on noncustodial parents was available in a small sample of families in Florida and Ohio (Sonenstein and Calhoun, 1988). More than half of the noncustodial parents in the Ohio sample, and about one-fourth in the Florida sample, were supposed to provide health insurance for their children. The authors could directly examine the insurance status of the noncustodial parents of 27 children who were uninsured: the noncustodial parents of 9 of these children had private coverage themselves, but only two reported that their children could have been covered under their health plan. In about one-third of the 59 cases in which the children received Medicaid only, the noncustodial parent had private coverage, but only 15 percent reported that their children could have been covered under their health plan.

Despite the low numbers of noncustodial parents of uninsured and Medicaid-only children who have coverage themselves, staff in 24 of 25 child support offices surveyed by Gordon (1991) believed that some increase in coverage would be possible if there were additional staff to process cases needing coverage, and 8 offices predicted increases of over 50 percent. However, only 3 offices thought that the "obligor has health insurance available at reasonable cost or through an employerrelated plan" in more than 50 percent of their cases.

Thus we have some research on the health care coverage of children in child-support-eligible families. However, the study that provides the best estimates (Sonenstein and Calhoun, 1988) was based on very small sample sizes (59 receiving Medicaid and 27 uninsured). Additional research on the potential for increasing the number of children covered through the insurance of their noncustodial parent is needed.

The Level of Child Support Awards and the Inclusion of Health Insurance

As a result of the Family Support Act of 1988, each state has a numerical formula (or guideline) for determining the amount of child support awards. States differ on how their guidelines for setting awards deal with health insurance. Under most guidelines, an amount spent for health 
insurance would decrease the cash award (Gordon, 1991). In Wisconsin, however, the cash award amount is to be set without considering health insurance costs, but "costs for health insurance" is listed as one of the reasons by which the court could deviate from the guideline.

One perspective on fairness is that insurance that does not cost the noncustodial parent should not change the amount of the award; if, however, providing insurance costs the noncustodial parent something, that amount should be subtracted from what would otherwise be provided in cash. While following this perspective keeps the amount of money transferred between the parents constant, it effectively decreases the freedom a custodial parent would have in spending the transfer in the way she or he believes is best for the child. This concern has led some observers to argue that medical insurance should be "an adjunct to, not a substitute for, the noncustodial parent's obligation to provide periodic financial support" (Goldfarb, 1987, p. 341). So information on whether health insurance is associated with lower cash awards (other things being equal) is important from an equity perspective. Further, this information is needed for an informed policy on how vigorously to pursue including health insurance in awards.

\section{DATA AND METHODS}

\section{$\underline{\text { Data }}$}

Two data sources are used in this research. The Current Population Survey-Child Support Supplement (CPS-CSS) is a nationally representative data set. In March of each year, information on income and health insurance coverage from the previous year is gathered, and in April 1990 (as in five previous Aprils) information about child support was collected. The March supplement provides basic information on the health insurance coverage of children in different types of families. The April supplement, for which over 4300 women were surveyed, offers specific information on whether the 
child support award included health insurance coverage from the noncustodial parent and whether that coverage was actually provided. ${ }^{4}$

The CPS-CSS provides no information on noncustodial parents. Therefore, another data set is needed to learn the income and employment levels of noncustodial parents of children who are uninsured or covered only by Medicaid. The second primary data source, the Wisconsin Court Record Data (WCRD), is based on a sample of divorce, separation, and paternity cases in which at least one child was eligible for child support (see Brown, Roan, and Marshall [1994] for more information on the WCRD). The data come from the records of cases that came to family court in twenty-one counties in Wisconsin during 1980-1989. Background information on both the mother and father is available, as well as whether medical insurance was required as part of the child support award. Income information from the Wisconsin Department of Revenue has been appended to these data to provide fuller income information on both parents.

Unfortunately, because the WCRD is an administrative record, limited demographic information is available. To gain more information, two Parents' Surveys (WPS) were completed on a subset of cases in the WCRD. The surveys cover families who came through the family courts in twenty Wisconsin counties between 1984 and June 1986 (Parents' Survey 1) and between July 1986 and 1988 (Parents' Survey 2). Information is available from at least one parent for more than 2700 couples. In addition to a variety of socioeconomic and demographic data on both parents and the children, the WPS contains specific information about health care coverage, including whether coverage was provided by the noncustodial parent and the type of coverage or combination of types (Medicaid, Medicare, employer/union plan, and/or individual plan). Noncustodial parents were asked about their income, employment, and their personal health coverage.

These data from Wisconsin may not be generalizable to the nation because they are from a state that has different demographics (fewer nonwhites), a higher rate of insurance coverage (AARP, 
1993), a more effective child support system than some other states, and higher welfare benefits than most other states. While the WCRD (used to determine whether cash awards are lower when health insurance is included) includes Milwaukee County, a large urban area, the WPS (used to examine the characteristics of noncustodial parents of uninsured and Medicaid-only children) does not. The two Wisconsin data sets are used because no nationally representative data set provides information on both noncustodial parents and their children. Only with data like these from Wisconsin can researchers explore whether uninsured children (or Medicaid-only children) have noncustodial parents who could provide health coverage.

\section{Methods}

The first two parts of the results are descriptive, providing information on the likelihood of having health coverage in a child support award and on the potential for increased coverage by noncustodial parents. To test whether child support awards are lower when medical coverage is included, I use equation (1):

(1) $A=\beta_{1} M+X_{1} \beta_{2}+\varepsilon$

where $A$ is the dollar amount of the award;

$M$ is a dummy variable indicating whether or not the award included medical coverage; and $X_{1}$ is a vector of control variables including characteristics of the noncustodial parent (like income and employment status), the custodial parent (income and AFDC receipt, for example), factors associated with the marriage/partnership (like the number of children), and institutional factors (the county in which the case was decided, for example).

A simple ordinary least squares equation is used. If the coefficient on medical coverage $\left(\beta_{1}\right)$ is negative, coverage is being treated as a substitute for cash, rather than as a supplement to the cash award. 


\section{RESULTS}

\section{$\underline{\text { Health Insurance Coverage and Child Support Awards }}$}

Table 1 shows information from the CPS-CSS on health coverage within child support awards. There are three points at which the child support system could fail to ensure that noncustodial parents provide health coverage to their children. First, the children may not receive a child support award of any type, cash or medical care. Second, even if there is a cash award, there may be no health insurance coverage provided in the award. Third, even when there is coverage in the award, it may not be provided by the noncustodial parent.

The first row summarizes the information already presented in the report on the CPS-CSS (U.S. Bureau of the Census, 1991a) ${ }^{5}$ : 42 percent of custodial-parent families do not have awards. ${ }^{6}$ Of those who do, almost 60 percent do not have coverage in their awards. And even when there is coverage, it is not provided in 32 percent of the cases.

But these averages hide much of the diversity experienced by custodial-parent families. The next panel shows that those with the most recent awards are the most likely to have health insurance in them, suggesting that the legislative push to make health coverage part of child support may be having some impact. Even the most recent awards, though, have health insurance only about half the time. There is also some trend toward more recent health insurance awards actually being provided.

The next panel shows the differences by current marital status of the mother. The proportion with an award varies enormously by marital status: more than three-fourths of custodial mothers who have not been married lack a child support award, as do about one-half of those who are separated, compared to fewer than one-fourth of the divorced or remarried women. Never-married women are also not likely to have coverage in their awards, even if they have an award. Remarried women are

less likely than divorced or separated women to have coverage in the award, perhaps because they are 
TABLE 1

Three Points at Which the Child Support System Can Fail to Ensure that Noncustodial Parents Provide Health Coverage

\begin{tabular}{|c|c|c|c|}
\hline & $\begin{array}{l}\text { Percent } \\
\text { without } \\
\text { Awards }\end{array}$ & $\begin{array}{c}\text { Of Those with Awards, } \\
\text { Percent without } \\
\text { Coverage in Award }\end{array}$ & $\begin{array}{l}\text { Of Those with } \\
\text { Coverage in } \\
\text { Awards, Percent } \\
\text { with Coverage } \\
\text { Not Provided }\end{array}$ \\
\hline All custodial mothers & 41.8 & 59.5 & 32.3 \\
\hline \multicolumn{4}{|c|}{ Year of most recent award revision } \\
\hline Before 1976 & NA & 80.7 & 26.4 \\
\hline 1976-1980 & NA & 63.8 & 44.9 \\
\hline 1981-1982 & NA & 61.8 & 35.9 \\
\hline $1983-1984$ & NA & 70.3 & 44.0 \\
\hline 1985-1986 & NA & 57.0 & 31.0 \\
\hline $1987-1988$ & NA & 57.6 & 26.0 \\
\hline 1989-1990 & NA & 50.8 & 28.4 \\
\hline \multicolumn{4}{|l|}{ Marital status } \\
\hline Never married & 75.7 & 73.4 & 42.0 \\
\hline Divorced & 22.6 & 54.8 & 32.9 \\
\hline Separated & 51.6 & 54.0 & 19.2 \\
\hline Remarried & 20.8 & 61.9 & 34.2 \\
\hline \multicolumn{4}{|c|}{ Comparison of family income to poverty line } \\
\hline Income $<50 \%$ poverty & 63.0 & 66.3 & 37.3 \\
\hline Income $51-100 \%$ poverty & 52.6 & 63.4 & 39.1 \\
\hline Income $101-200 \%$ poverty & 42.3 & 56.1 & 35.5 \\
\hline Income $201-300 \%$ poverty & 29.4 & 58.2 & 29.1 \\
\hline Income $301 \%+$ poverty & 24.0 & 58.2 & 27.6 \\
\hline $\mathrm{N}$ & 4249 & 2517 & 1006 \\
\hline
\end{tabular}

Source: Current Population Survey-Child Support Supplement 1990.

Note: Sample is custodial-mother families with children under 21. 
more likely to have coverage through their new family. The third column shows that separated women are most likely to have coverage actually provided if it is in the award.

There are also some differences by poverty status. The poorest families are least likely to have a child support award, but once they have an award, they are only slightly less likely to have coverage in the award. When coverage is ordered, the poor are somewhat less likely to receive it.

But Table 1 only focuses on whether fathers provide coverage. Even if the father does not provide coverage, the children may still be covered through their mothers. Table 2 examines whether the children have health insurance coverage in three types of families: (1) families who do not have cash awards; (2) families who have cash awards, but do not have health coverage in their awards; and (3) families who have health coverage in their awards but the custodial parent reported that it was not provided. I focus on the percent uninsured and the percent with public insurance only, since if those with public insurance only could also be covered by private health insurance, taxpayers would save money.

The first two columns show that 17.8 percent of the youngest children in custodial-parent families without awards are uninsured, and another 37 percent have public insurance only. ${ }^{7}$ As expected, this rate is higher than the rate for all children, which in March 1990 was 13.6 percent uninsured and 12.3 percent with Medicaid only (U.S. Bureau of the Census, 1991b). Moreover, it is higher than the rate for the youngest child in all child-support-eligible families, which is 14.9 percent uninsured and 25.2 percent with public insurance only (not shown in table). Of those without awards, children living with mothers who have never been married are most likely to have public insurance only, but are not more likely to be uninsured. Those without awards who have fairly high incomes are less likely to be uninsured, and the percentage with only public insurance declines dramatically as income increases. 
TABLE 2

Children's Health Coverage in Custodial-Parent Families

\begin{tabular}{|c|c|c|c|c|c|c|}
\hline & \multicolumn{2}{|c|}{$\begin{array}{l}\text { Of Those Without } \\
\text { Awards } \\
\end{array}$} & \multicolumn{2}{|c|}{$\begin{array}{l}\text { Of Those Without } \\
\text { Coverage in Awards }\end{array}$} & \multicolumn{2}{|c|}{$\begin{array}{c}\text { Of Those } \\
\text { With Coverage in } \\
\text { Awards, Not Provided }\end{array}$} \\
\hline & $\begin{array}{l}\text { Uninsured } \\
(\%)\end{array}$ & $\begin{array}{l}\text { Public } \\
\text { Ins. Only } \\
(\%)\end{array}$ & $\begin{array}{l}\text { Uninsured } \\
\quad(\%)\end{array}$ & $\begin{array}{l}\text { Public } \\
\text { Ins. Only } \\
(\%)\end{array}$ & $\begin{array}{l}\text { Uninsured } \\
(\%)\end{array}$ & $\begin{array}{l}\text { Public } \\
\text { Ins. Only } \\
(\%)\end{array}$ \\
\hline Youngest child of custodial mother & 17.8 & 37.4 & 13.1 & 19.4 & 16.0 & 22.9 \\
\hline \multicolumn{7}{|l|}{ Year of most recent award revision } \\
\hline Before 1976 & NA & NA & 6.6 & 14.2 & 1.8 & 28.4 \\
\hline 1976-1980 & NA & NA & 14.5 & 8.6 & 14.0 & 13.5 \\
\hline 1981-1982 & NA & NA & 14.5 & 14.7 & 18.9 & 17.9 \\
\hline 1983-1984 & NA & NA & 12.0 & 21.9 & 31.4 & 17.2 \\
\hline 1985-1986 & NA & NA & 11.9 & 19.6 & 17.8 & 27.9 \\
\hline 1987-1988 & NA & NA & 13.8 & 23.2 & 11.2 & 24.1 \\
\hline 1989-1990 & NA & NA & 14.2 & 26.2 & 13.7 & 28.9 \\
\hline \multicolumn{7}{|l|}{ Marital status } \\
\hline Never married & 17.6 & 48.3 & 13.2 & 49.0 & 26.4 & 35.3 \\
\hline Divorced & 17.2 & 28.3 & 15.9 & 18.9 & 15.7 & 25.7 \\
\hline Separated & 22.5 & 33.0 & 16.8 & 34.4 & 3.2 & 57.3 \\
\hline Remarried & 13.6 & 9.7 & 9.1 & 3.4 & 16.0 & 7.7 \\
\hline \multicolumn{7}{|c|}{ Comparison of family income to poverty line } \\
\hline Income $<50 \%$ poverty & 19.7 & 63.4 & 18.1 & 63.7 & 13.3 & 74.0 \\
\hline Income $51-100 \%$ poverty & 18.8 & 57.9 & 20.0 & 52.4 & 27.8 & 44.4 \\
\hline Income $101-200 \%$ poverty & 22.0 & 20.1 & 20.1 & 8.4 & 20.8 & 20.0 \\
\hline Income $201-300 \%$ poverty & 16.3 & 4.9 & 10.3 & 1.6 & 13.9 & 8.8 \\
\hline Income $301 \%+$ poverty & 7.0 & 2.3 & 4.4 & 1.1 & 7.7 & 0.0 \\
\hline $\mathrm{N}$ & \multicolumn{2}{|c|}{1732} & \multicolumn{2}{|c|}{1511} & \multicolumn{2}{|c|}{320} \\
\hline
\end{tabular}

Source: Current Population Survey-Child Support Supplement 1990.

Notes: Sample is youngest child eligible for child support in custodial-mother families with children under 21. Private insurance includes all children with private insurance, even if they also have public insurance. Public insurance includes Medicaid, Medicare, and military health programs. 
The next two columns show that children with cash awards but no health insurance coverage in their award are somewhat better off than those without awards, with 13 percent uninsured and 19 percent receiving public insurance only. The year of the most recent award revision appears to make little difference, except in that recent awards are more likely to have public insurance only, perhaps reflecting increasing numbers of never-married women. Again, children of never-married women are most likely to have public insurance only, but they are not the most likely to be uninsured. As before, children in families with incomes less than 200 percent of the poverty line are somewhat more likely to be uninsured, and those in families with incomes below the poverty line are much more likely to have public insurance only.

The last two columns show that 16 percent of the children in families in which the father was supposed to provide health insurance, but did not do so, are uninsured. Another 23 percent of these children receive public insurance only.

\section{The Potential for Increasing Private Coverage through Noncustodial Parents}

The WPS enables us to examine the noncustodial parents of children who are not covered by private insurance. (Some of these noncustodial parents have been ordered to provide insurance but do not do so; others have not been ordered at all.) In the WPS, information on the children's coverage status is solicited from both the custodial and noncustodial parent. Further, information on the noncustodial parent's income is solicited from both parents. Unfortunately, income and coverage information is not consistently present. In the main tables reported here, I use custodial reports of insurance coverage, when available, and noncustodial reports when there is no custodial report. For the noncustodial parent's income, I use the noncustodial report, when available, then use the Wisconsin income tax record, then, if income information is still missing, I accept the custodial parent's estimate. The effects of these choices are discussed in Appendix A. 
Table 3 presents information on the coverage status of children in custodial-parent families who have been through court in twenty counties in Wisconsin. The sample in this table differs from the national sample in Tables 1 and 2 (in addition to being from Wisconsin only) in several regards: (1) Table 3 only includes families who have come to court, so it does not include never-married women who have not had paternity established; (2) Table 3 includes few minorities, and no children who live in a major urban area; (3) Table 3 includes custodial fathers; (4) information about the noncustodial parent is available in Table 3 but not in Tables 1 or 2 . Because several of the groups that are underrepresented in Table 3 (minority parents, those in central cities, and never-married parents who have not had paternity established) are more likely to be poor, one would expect Table 3 to show a lower rate of uninsurance than Tables 1 and 2, which displayed information for a national sample. Further, Wisconsin has a higher rate of insurance coverage than the nation (AARP, 1993). Indeed there is a lower rate of uninsurance (3.7 percent) and public insurance coverage (23.7 percent $)^{8}$ than in the national sample. In the nation as a whole in March 1990, 16.4 percent of the children living in families with a female householder with no spouse present were uninsured, and 36.7 percent were covered by Medicaid only (U.S. Bureau of the Census, 1991b). As expected, children from paternity cases in Wisconsin are somewhat more likely to be uninsured and much more likely to have public insurance only.

The information gained from this sample is information on the noncustodial parent. Most of these parents are between 21 and 40; the younger the parent, the more likely his children are uninsured. The survey reveals higher rates of uninsurance for children of African American noncustodial parents, but keep in mind that the sample size is small. As might be expected, the children of noncustodial parents who do not have high school educations are more likely to be uninsured or have public insurance only. Finally, the highest rates of uninsurance for children are among those whose noncustodial parents have missing income information or have between $\$ 1$ and 
TABLE 3

Children's Health Coverage in Custodial-Parent Families in Wisconsin

\begin{tabular}{|c|c|c|c|c|c|}
\hline & Uninsured & $\begin{array}{l}\text { Private } \\
\text { Insurance }\end{array}$ & $\begin{array}{l}\text { Only } \\
\text { Public } \\
\text { Insurance }\end{array}$ & $\begin{array}{l}\text { Public Insurance, } \\
\text { Private Insurance } \\
\text { Coverage Unknown }\end{array}$ & N Known \\
\hline All & 3.7 & 72.6 & 22.8 & 0.9 & 2736 \\
\hline \multicolumn{6}{|l|}{ Case type } \\
\hline Paternity & 6.0 & 40.2 & 52.2 & 1.6 & 646 \\
\hline Divorce & 3.0 & 82.5 & 13.8 & 0.7 & 2090 \\
\hline 1 Child & 3.8 & 81.8 & 14.1 & 0.3 & 753 \\
\hline 2 Children & 3.0 & 83.1 & 13.0 & 0.9 & 927 \\
\hline 3+ Children & 1.5 & 82.7 & 14.9 & 1.0 & 410 \\
\hline \multicolumn{6}{|c|}{ Parent with physical custody } \\
\hline Mother & 3.8 & 71.4 & 24.0 & 0.8 & 2516 \\
\hline Father & 3.2 & 85.9 & 9.5 & 1.4 & 220 \\
\hline \multicolumn{6}{|c|}{ Information about Noncustodial Parent } \\
\hline \multicolumn{6}{|c|}{$\overline{\text { Age }}$} \\
\hline$<=20$ & 8.3 & 33.3 & 53.7 & 4.6 & 108 \\
\hline $21-30$ & 4.8 & 61.0 & 33.4 & 0.7 & 1116 \\
\hline $31-40$ & 2.5 & 83.0 & 14.0 & 0.5 & 1062 \\
\hline $41+$ & 2.5 & 87.8 & 9.0 & 0.7 & 433 \\
\hline \multicolumn{6}{|l|}{ Race } \\
\hline White & 3.7 & 73.8 & 21.8 & 0.8 & 2630 \\
\hline African American & 7.0 & 36.8 & 56.1 & 0.0 & 57 \\
\hline Other & 2.6 & 47.4 & 47.4 & 2.6 & 38 \\
\hline \multicolumn{6}{|l|}{ Education } \\
\hline$<$ High school & 6.3 & 49.6 & 42.8 & 1.3 & 397 \\
\hline High school grad & 4.2 & 72.4 & 22.7 & 0.7 & 1180 \\
\hline Some college & 3.1 & 78.1 & 17.9 & 0.8 & 747 \\
\hline College graduate & 0.8 & 92.8 & 6.4 & 0.0 & 359 \\
\hline \multicolumn{6}{|c|}{ Annual personal income } \\
\hline Unknown & 6.5 & 45.2 & 44.8 & 3.5 & 431 \\
\hline Zero & 3.7 & 68.8 & 25.7 & 1.8 & 109 \\
\hline$\$ 1-\$ 10,000$ & 5.6 & 48.8 & 44.4 & 1.2 & 498 \\
\hline$\$ 10,001-\$ 15,000$ & 5.8 & 65.4 & 28.5 & 0.3 & 312 \\
\hline$\$ 15,001-\$ 20,000$ & 2.0 & 84.2 & 13.8 & 0.0 & 354 \\
\hline$\$ 20,001-\$ 30,000$ & 2.3 & 92.1 & 5.6 & 0.0 & 534 \\
\hline$\$ 30,001-\$ 50,000$ & 1.3 & 95.1 & 3.6 & 0.0 & 392 \\
\hline$\$ 50,001+$ & 0.0 & 99.1 & 0.9 & 0.0 & 106 \\
\hline
\end{tabular}

Source: Wisconsin Parents' Survey I and II.

Notes: Sample is one random child per family. Those whose parents reconciled, those who live together, and those with no children under age 18 in the reference year have been excluded. Private insurance includes all children with private insurance, even if they also have public insurance. Public insurance includes Medicaid and Medicare. Income information is from the noncustodial parent's report on the survey, or, if missing, from the tax record, or, if missing there, from the custodial parent's report on the survey. Income is reported in 1988 dollars. Information about insurance status, about children, and about the custodial parent comes from the custodial parent, or, if unknown, from the noncustodial parent. Information about the noncustodial parent comes from the noncustodial parent, or, if unknown, from the custodial parent. Except in the income panels, those with missing data are excluded. 
$\$ 15,000$ in annual personal income. None of the children whose noncustodial parent has over $\$ 50,000$ in income are uninsured. The highest rates of public insurance only are for noncustodial parents with unknown income and those with incomes between $\$ 1$ and $\$ 10,000$. Few of the children of noncustodial parents with higher incomes receive public insurance only.

More specific pictures of the noncustodial parents of the uninsured and Medicaid-only children in the Wisconsin sample are given in Table 4. The first row shows that there are 102 uninsured children in the Wisconsin data base and 617 children receiving Medicaid only. Unfortunately, information on both health insurance coverage and income is known for fewer than half of the noncustodial parents, limiting the conclusions that can be drawn. Among those for whom health insurance status and income are known, fewer than half (43 percent and 44 percent, respectively) report that they are insured.

The number of noncustodial parents who could be providing coverage is probably limited to the group with coverage themselves, or fewer than half the cases. But even among these, the number who could cover their children depends in part on whether family coverage is available to them at little or no cost. If it is available at little or no cost, then any of the parents with personal coverage could be providing insurance to their uninsured children, or 43 percent and 44 percent of those with nonmissing information, as shown in row $2 \mathrm{~A}$. But if family coverage is available only at significant costs, then only those who have moderate incomes (perhaps above $\$ 20,000$ ) could be expected to provide coverage, or only 21 percent of the sample with nonmissing information for uninsured children and 8 percent for Medicaid-only children (row 2A1).

The conclusions one can draw depend a great deal on the characteristics of those with missing information. Under the most optimistic scenario, those with missing information are similar to those with information, and all noncustodial parents with private health insurance could cover their children 
TABLE 4

\section{Characteristics of Noncustodial Parents of Uninsured Children and Children Receiving Medicaid Only in Custodial-Parent Families in Wisconsin}

\begin{tabular}{|c|c|c|}
\hline & $\begin{array}{l}\text { Uninsured } \\
\text { Children }\end{array}$ & $\begin{array}{l}\text { Medicaid-Only } \\
\text { Children }\end{array}$ \\
\hline 1. Number of children & 102 & 617 \\
\hline $\begin{array}{l}\text { 2. Percent of these in which both the insurance } \\
\text { status and income of the noncustodial parent } \\
\text { are known }\end{array}$ & $41 \%$ & $47 \%$ \\
\hline Of these: & & \\
\hline $\begin{array}{l}\text { 2A. Noncustodial parent has personal health } \\
\text { insurance coverage } \\
\text { 2A1. And noncustodial income over } \$ 20,000 \\
\text { 2A2. And noncustodial income } \$ 10,001-\$ 20,000 \\
\text { 2A3. And noncustodial income } \$ 10,000 \text { or less }\end{array}$ & $\begin{array}{l}43 \% \\
21 \% \\
14 \% \\
7 \%\end{array}$ & $\begin{array}{r}44 \% \\
8 \% \\
20 \% \\
16 \%\end{array}$ \\
\hline $\begin{array}{l}\text { 2B. Noncustodial parent does not have personal health } \\
\text { insurance coverage } \\
\text { 2B1. And noncustodial income over } \$ 20,000 \\
\text { 2B2. And noncustodial income } \$ 10,001-\$ 20,000 \\
\text { 2B3. And noncustodial income } \$ 10,000 \text { or less }\end{array}$ & $\begin{array}{r}57 \% \\
7 \% \\
26 \% \\
24 \%\end{array}$ & $\begin{array}{r}56 \% \\
5 \% \\
14 \% \\
37 \%\end{array}$ \\
\hline $\begin{array}{l}\text { 3. Percent of children who could be covered: } \\
\text { 3A. Optimistic scenario (row } 2 \mathrm{~A} \text { ) } \\
\text { 3B. Pessimistic scenario (row } 2 \mathrm{~A} 1 * \text { row } 2 \text { ) }\end{array}$ & $\begin{array}{c}43 \% \\
9 \%\end{array}$ & $\begin{array}{c}44 \% \\
4 \%\end{array}$ \\
\hline
\end{tabular}

Source: Wisconsin Parents' Survey I and II.

Notes: Sample is one random child per family. Those whose parents reconciled, those who live together, and those with no children under age 18 in the reference year have been excluded. Noncustodial parent income is from the noncustodial parent's report on the parent's survey, or, if missing there, from the tax record, or, if missing there, from the custodial parent's report on the parents' survey. It is reported here in 1988 dollars. Information about noncustodial parent health coverage comes from the noncustodial parent, or, if unknown, from the custodial parent. Information about the child support award comes from the Wisconsin Court Record. 
at nominal cost. Then more than 40 percent (row 3A) of the uninsured children and the children receiving Medicaid only could be insured through their noncustodial parent.

However, the optimistic scenario is an unlikely one. Those missing information are likely to be somewhat worse off than those for whom we have information for two reasons. First, those who could not be found (or those found but not responding to a survey) may have lower socioeconomic status than those who do respond. Second, those missing income information could be missing it because their income was too low to file a Wisconsin tax return (it could also be missing because they had moved out of Wisconsin). A simple analysis of the missing cases suggests that those missing information are worse off than those with full information. ${ }^{9}$

Another reason the optimistic scenario is unlikely is that family coverage is not always available at nominal cost; in fact, recent trends are for increasing cost-sharing between employers and employees (Sheils \& Wolfe, 1992). An examination of the March 1990 CPS reveals that only 34 percent of the divorced men under age sixty-five who have private insurance have it paid for completely by their employer or union; another 48 percent have it partially paid for by their employer or union. Therefore, a pessimistic scenario (but probably closer to the truth) would be that none of those with missing information could provide coverage, and only those with incomes over $\$ 20,000$ who were covered themselves could provide coverage. This means that 9 percent (from 21 percent of 43 percent) of the uninsured children could be covered by their noncustodial parent (shown in row 3B), and 4 percent of the children receiving only Medicaid could be. Of course, if even one child who does not have insurance could receive it if the child support system paid careful attention, the benefit to that child is obvious (but this benefit should be weighed against the costs of gaining this insurance and enforcing its continued provision). 
The Level of Child Support Awards and the Inclusion of Health Insurance

Table 5 examines whether child support awards in Wisconsin are lower when medical insurance is included. Because child support awards in Wisconsin are supposed to vary with the number of children, separate results are presented for families with one child, with two children, and with three or more. Further, since the effect of the inclusion of medical support on award amounts may differ for paternity and divorce cases, these are also separated. The sample for these estimates includes women who had physical custody of their child(ren), who came to court between January 1984 and January 1989, and who had a child support award. The woman's first award is used for the amount and for whether health insurance was supposed to be provided. Variable definitions and means are presented in Appendix B. Recall that if the coefficient on "INSURANCE IN AWARD" is significantly different from zero and negative, insurance is being treated as a substitute for cash.

The first three sets of columns are for divorce cases. For one child, the cash amount of an award is significantly higher when health insurance is included, challenging the hypothesis that health insurance may be treated as a substitute for cash. For two or more children, the coefficients are positive, but not significantly different from zero. The last columns show paternity cases with one child. In the vast majority of paternity cases (about 80 percent), health insurance information is missing; of those cases for which insurance information is present, few have insurance as part of the awards. Again the insignificant coefficient in the first row shows that the cash value of awards that include health insurance is not significantly lower than the cash value of those without insurance.

These results may simply be reflecting unobserved factors that lead some types of noncustodial parents to have higher obligations and to provide health insurance, perhaps because they have well-paying jobs in firms that provide family health insurance to their employees. ${ }^{10}$ A more complicated estimation, in which the probability of having health insurance in the award is explicitly modeled and the error term in the health insurance equation is allowed to be correlated with the error 
TABLE 5

Determinants of the Amount of Child Support Awards in Wisconsin

\begin{tabular}{|c|c|c|c|c|c|c|c|c|}
\hline & \multicolumn{2}{|c|}{ Divorce-One Child } & \multicolumn{2}{|c|}{ Divorce-Two Children } & \multicolumn{2}{|c|}{ Divorce-Three+ Children } & \multicolumn{2}{|c|}{ Paternity } \\
\hline & Coeff. & Std. Err. & Coeff. & Std. Err. & Coeff. & Std. Err. & Coeff. & Std. Err. \\
\hline INSURANCE IN AWARD & 371.1 & $211.4 *$ & 317.7 & 241.5 & 506.9 & 583.6 & -30.1 & 194.9 \\
\hline \multicolumn{3}{|c|}{ MISSING INSURANCE STATUS } & & & & & 18.8 & 82.8 \\
\hline DAD INCOME & 67.1 & $7.7 * * *$ & 75.9 & $5.5 * * *$ & 105.1 & $6.5 * * *$ & 67.1 & $4.7 * * *$ \\
\hline DAD EMPLOYED & 190.6 & 295.8 & 1037.5 & $317.1 * * *$ & -300.4 & 681.9 & 337.8 & $100.3 * * *$ \\
\hline DAD AGE & 78.0 & $16.6 * * *$ & 64.8 & $21.0 * * *$ & 3.3 & 45.9 & 3.2 & 4.9 \\
\hline CHILD AGE & -11.9 & 29.6 & -43.1 & 30.4 & 37.5 & 69.3 & -29.6 & $15.6^{*}$ \\
\hline MOM INCOME & -26.9 & $14.6^{*}$ & -37.3 & $11.5 * * *$ & 174.8 & $22.1 * * *$ & 0.9 & 9.9 \\
\hline MOM AFDC & -760.0 & $220.9 * * *$ & -1518.8 & $234.3 * * *$ & -2004.6 & $547.6 * * *$ & -181.3 & $76.3 * *$ \\
\hline MILWAUKEE & 233.5 & 220.7 & 221.8 & 252.5 & 2182.6 & $608.1 * * *$ & 122.4 & 76.6 \\
\hline AWARD 1985 & -683.6 & $272.2 * *$ & -476.5 & $281.9 *$ & -1111.5 & $664.2 *$ & -63.5 & 104.0 \\
\hline AWARD 1986 & -610.5 & $271.1 * *$ & -304.9 & 276.6 & 231.1 & 651.1 & 13.1 & 99.9 \\
\hline AWARD 1987 & -845.9 & $302.3 * * *$ & -261.6 & 319.6 & -1299.0 & $718.5^{*}$ & -2.0 & 107.8 \\
\hline AWARD 1988-1989 & -956.3 & $360.5 * * *$ & 450.9 & 398.7 & -1299.7 & 950.7 & 173.5 & 115.7 \\
\hline INTERCEPT & -90.6 & 609.5 & 986.4 & 752.0 & 1574.0 & 1706.0 & 607.9 & $193.3 * * *$ \\
\hline $\mathrm{R}$ squared & & .16 & & .27 & & .48 & & .26 \\
\hline $\mathrm{N}$ & & 1031 & & 1148 & & 536 & & 955 \\
\hline
\end{tabular}

*** Significantly different from zero, .01 level.

** Significantly different from zero, .05 level.

* Significantly different from zero, .10 level.

Source: Wisconsin Court Record Data.

Notes: Sample is paternity and divorced mothers in the WCRD who came to court between January 1, 1984, and January 31, 1989. Those with missing information on father's age, child's age, or mother's social security number were deleted. Those with more than one child listed in the paternity action were deleted from the paternity equation. Those with missing health insurance status were deleted from the divorce equations. The equation also included dummy variables for fathers whose incomes were missing, for fathers whose employment status was missing, and for mothers whose incomes were missing. Coefficients for these variables are available from the author on request. 
term in the award amount equation, also fails to find a significant negative relationship between health insurance and the cash award amount (results not shown here). ${ }^{11}$

The coefficients on the other variables usually have the expected signs. In general, awards are generally higher when father's income is higher, when the main source of father's income is employment (as opposed to self-employment or transfer income), when the father is older, and when the child is younger (paternity cases only). For divorce cases with one or two children, awards are lower when the custodial parent's income is higher, but the opposite is true for families with three or more children. Cash awards for divorced families with one child were lower after 1984, but this is because two cases from 1984 had very large awards. Perhaps the most notable coefficient is on mother's use of AFDC. One could reasonably hypothesize that, all else being equal, courts grant higher child support awards to custodial parents who receive AFDC, since this would potentially lower taxpayer expenditures. This hypothesis, however, is not supported by the results in Table 5. In fact, mothers on AFDC receive lower cash awards, even when the father's income is held constant.

\section{SUMMARY AND POLICY IMPLICATIONS}

\section{$\underline{\text { Summary }}$}

Is the child support system doing all it can to provide children with health insurance coverage? The national data show that about 40 percent of all child support awards include health insurance coverage as part of the award. Even when coverage is required in awards, however, it is not always provided. Does this matter? The evidence shown here suggests that it does: 18 percent of children whose mothers lack awards are uninsured, 13 percent whose mothers have awards without health coverage in them are uninsured, and 16 percent whose fathers were not providing the coverage they had been ordered to provide were unable to receive insurance from another source and were uninsured. 
But is it reasonable to expect a large number of the uninsured children in custodial-parent families (or children receiving Medicaid only) to be covered by noncustodial parent insurance? Unfortunately, the only data that provide information on both the noncustodial parent and the child's health coverage status have a great deal of missing information. While the most optimistic estimates suggest that about 40 percent of the uninsured and Medicaid-only could be covered, a more pessimistic (and probably more realistic) estimate is that fewer than 10 percent could be covered. This suggests that there is not an enormous group of children who would receive private insurance coverage if the child support system were to pay more attention to ensuring medical support.

On the other hand, the results presented here show no support for the hypothesis that including health insurance coverage in awards will only lead to lower cash awards.

\section{$\underline{\text { Policy Implications }}$}

There is clearly a need, given the current health care system, to provide children with health insurance. This could be the responsibility of the custodial parent, of the noncustodial parent, of government, or of some combination. Recent child support policy has attempted to increase the role of the noncustodial parent in providing coverage. There is a long way to go, since the national data show that medical support is still not always ordered; however, the potential for improvement exists, with the Wisconsin data showing that some noncustodial parents who are not covering their children are insured themselves and have modest incomes. Perhaps many awards do not include health insurance because the noncustodial father who must pay the award earns little money and cannot afford to provide coverage at the time the award is set. Research has shown that the incomes of noncustodial parents, particularly those in paternity cases, increase sizably over the years (Phillips \& Garfinkel, 1993; Meyer, 1993). If this is true, child support agencies may want to seek "conditional" health insurance awards that become effective at any point in time when it is discovered that the noncustodial parent can provide it. These conditional orders would allow child support agencies to 
pursue medical insurance without needing to formally modify the award. Or perhaps the problem is not enough attention is paid to enforcing medical support orders once they are made. However, with an already overburdened child support staff, enforcing all orders may be impossible. Selective enforcement activities may be a prudent course of action; enforcement may be especially productive if focused on cases in which the employer withholds cash child support (presumably all cases decided after January 1994, and some cases decided before this time), since in these cases a medical support order could be administered by the employer.

But the larger picture is that children need health insurance coverage, and expecting this to be solely the noncustodial parent's responsibility may be unwise. Some noncustodial parents do not have coverage themselves, while others have coverage for themselves but would have to pay large amounts to have their children covered. In other cases it may be more appropriate for the custodial parent to provide coverage (for example, when the noncustodial parent has a geographically limited HMO, and the children live elsewhere). And the possibility remains that noncustodial parents may limit the amount of cash they contribute if they are forced to provide insurance coverage. While requiring noncustodial parents to provide coverage when possible is a policy that makes sense, we also need to ensure that children whose noncustodial parents cannot provide coverage are fully covered through broader health care reform. 


\section{APPENDIX A}

\section{Effects of Using Other Procedures when Children's Insurance Status or Noncustodial Income Is Missing}

The results reported in Tables 3 and 4 are based on the following assumptions:

- I assume that the custodial parent is the most accurate reporter of the child's health insurance status. However, several types of custodial parents were not asked about the child's insurance (e.g., those with legal or informal agreements in which no cash was to be transferred). Because there is substantial agreement about the child's insurance status when both parents report it, I accepted the noncustodial parent's report of the child's insurance status if the custodial parent's report was missing.

- I assume that the noncustodial parent is the most accurate reporter of his or her own income. However, all noncustodial parents were not interviewed, and in some cases in which there was an interview, income was missing. When noncustodial parent income was missing, I accepted the report of personal income reported on Wisconsin income taxes in the Wisconsin Department of Revenue file. If both these sources were missing, I accepted the custodial parent's estimate of the noncustodial parent's income.

To assess whether the results presented here are sensitive to these assumptions, I calculated results under three other assumptions:

A. Noncustodial parents' reports of child insurance status are not accurate (and were not used).

B. Custodial parents' reports of noncustodial parent's income are not accurate (and were not used).

C. Both of the above are true, so the proxy reports were not used.

Changes in Table 3: Appendix Table 1 shows some selected results from incorporating the alternative assumptions. The first row repeats information from Table 3. The second row shows that not using the noncustodial parent's reports of child insurance status (assumption A) decreases the number of cases in which we know the health coverage of the child from 2736 to 2386 . The two rows are quite similar, however, on the health coverage status of children.

The next panel shows collapsed information already reported in Table 3 on the noncustodial parent's income. Changing the way the child's health insurance status is determined (assumption A) decreases the total sample (as was shown in the earlier rows). Again, most rows are quite similar to the Table 3 results. Not accepting a custodial parent's report of the noncustodial parent's income (assumption B) increases the number of noncustodial parents with unknown income from 431 to 521, but again the general conclusions are similar. Finally, assumption $\mathrm{C}$ also provides quite similar results to the information provided in Table 3. 
APPENDIX TABLE 1

Table 3 under Different Assumptions

\begin{tabular}{|c|c|c|c|c|c|}
\hline & Uninsured & $\begin{array}{l}\text { Private } \\
\text { Insurance }\end{array}$ & $\begin{array}{l}\text { Only } \\
\text { Public } \\
\text { Insurance }\end{array}$ & $\begin{array}{l}\text { Public Insurance, } \\
\text { Private Insurance } \\
\text { Coverage Unknown }\end{array}$ & N Known \\
\hline As reported in Table 3 & 3.7 & 72.6 & 22.8 & 0.9 & 2736 \\
\hline If use assumption $\mathrm{A}$ & 4.0 & 70.6 & 23.3 & 2.1 & 2386 \\
\hline \multicolumn{6}{|c|}{ Annual personal income as reported: } \\
\hline Unknown & 6.5 & 45.2 & 44.8 & 3.5 & $431(16 \%)$ \\
\hline Zero & 3.7 & 68.8 & 25.7 & 1.8 & $109(4 \%)$ \\
\hline$\$ 1-\$ 20,000$ & 4.6 & 64.0 & 30.8 & 0.6 & $1164(43 \%)$ \\
\hline$\$ 20,001+$ & 1.7 & 94.0 & 4.4 & 0.0 & $1032(38 \%)$ \\
\hline \multicolumn{6}{|c|}{ Annual personal income using assumption A: } \\
\hline Unknown & 6.8 & 44.0 & 45.5 & 3.7 & $411(17 \%)$ \\
\hline Zero & 3.3 & 67.4 & 21.7 & 7.6 & $92 \quad(4 \%)$ \\
\hline$\$ 1-\$ 20,000$ & 4.7 & 62.3 & 30.3 & 2.7 & $1023(43 \%)$ \\
\hline$\$ 20,001+$ & 1.9 & 93.5 & 4.5 & 0.1 & $860(36 \%)$ \\
\hline \multicolumn{6}{|c|}{ Annual personal income using assumption B: } \\
\hline Unknown & 5.8 & 51.6 & 39.5 & 3.1 & $521(19 \%)$ \\
\hline Zero & 3.7 & 68.8 & 25.7 & 1.8 & $109 \quad(4 \%)$ \\
\hline$\$ 1-\$ 20,000$ & 4.6 & 63.8 & 31.1 & 0.5 & $1116(41 \%)$ \\
\hline$\$ 20,001+$ & 1.7 & 93.8 & 4.4 & 0.0 & $990(36 \%)$ \\
\hline \multicolumn{6}{|c|}{ Annual personal income using assumption C: } \\
\hline Unknown & 6.0 & 50.9 & 39.9 & 3.2 & $501(21 \%)$ \\
\hline Zero & 3.3 & 67.4 & 21.7 & 7.6 & $92(4 \%)$ \\
\hline$\$ 1-\$ 20,000$ & 4.7 & 62.0 & 30.6 & 2.8 & $975(41 \%)$ \\
\hline$\$ 20,001+$ & 2.0 & 93.3 & 4.7 & 0.1 & $818(34 \%)$ \\
\hline
\end{tabular}

Changes in Table 4: In the column for uninsured children, not using the noncustodial parent's report of the child's insurance coverage (assumptions A and C) decreases the number of uninsured children from 102 to 95 . While the number of cases with full information declines when we no longer accept proxy reports, again the substantive conclusions of the table do not change. Under each set of assumptions, 21-24\% of those with known income and insurance status have incomes over $\$ 20,000$ and personal insurance. Of those with known income and insurance status, between $41 \%$ (assumption C) and 50\% (Table 4, row 2B2 + 2B3) have no coverage and incomes of $\$ 20,000$ or less. Further, the group with unknown insurance status and known incomes (not shown in Table 4) is a low-income group under any set of assumptions, with 58\% to 59\% of those with unknown insurance and known income having incomes less than $\$ 10,000$. The percentage of children who could be covered in the optimistic scenario varies from $43 \%$ (Table 4) to $51 \%$ (assumption C). The percentage who could be covered in the pessimistic scenario varies from $8 \%$ to $9 \%$.

In the columns for Medicaid-only children, not using the noncustodial parent's report of the child's insurance coverage (assumptions A and C) decreases the number of children receiving Medicaid only from 617 to 551 . While the number of cases with full information declines when we no longer accept proxy reports, again the substantive conclusions of the table do not change. Under each set of assumptions, 8-9\% of those with known income and insurance status have incomes over $\$ 20,000$ and personal insurance. Of those with known income and insurance status, between $45 \%$ (assumptions A and C) and 51\% (Table 4, row 2B2 + 2B3, and assumption B) have no coverage and incomes of $\$ 20,000$ or less. Further, the group with unknown insurance status and known incomes (not shown) is a low-income group under any set of assumptions, with $66 \%$ to $68 \%$ of those with unknown insurance and known income having incomes less than $\$ 10,000$. The percentage of children who could be covered in the optimistic scenario varies from $44 \%$ (Table 4 ) to $50 \%$ (assumption C). The percentage who could be covered in the pessimistic scenario is $4 \%$ under any of these assumptions.

In conclusion, while not accepting proxy reports changes the sample size, the pattern of results is not sensitive to the assumptions. 
APPENDIX B

Means and Definitions of Variables Used

\begin{tabular}{lrrrr}
\hline & & & & Divorce \\
& Paternity & One Child & Two Children & Three+ Children \\
\hline AWARD (\$) & 1497 & 3027 & 4821 & 6605 \\
& & & & .80 \\
INSURANCE IN AWARD & .03 & .74 & .79 & \\
MISSING INSURANCE STATUS & .81 & & & 24.61 \\
& & & & .15 \\
DAD INCOME (\$1000s) & 8.56 & 16.82 & 20.60 & .70 \\
MISSING DAD INCOME & .28 & .17 & .14 & .16 \\
DAD EMPLOYED & .66 & .70 & .73 & 37.72 \\
MISSING DAD EMPLOYMENT & .23 & .19 & .16 & 9.23 \\
DAD AGE & 26.53 & 31.55 & 33.69 & .20 \\
CHILD AGE & 1.63 & 5.10 & 5.98 & .27 \\
MOM INCOME (\$1000s) & 2.73 & 9.83 & .10 .72 & .20 \\
MISSING MOM INCOME & .58 & .17 & .29 & .23 \\
MOM AFDC & .80 & .33 & .22 & .25 \\
MILWAUKEE & .11 & .30 & .25 & .19 \\
AWARD 1985 & .23 & .24 & .27 & .08 \\
AWARD 1986 & .29 & .26 & .18 & .09 \\
AWARD 1987 & .20 & .18 & & 536 \\
AWARD 1988-1989 & .16 & .11 & 1148 & \\
N & 955 & 1031 & & \\
\hline
\end{tabular}

Definitions:

INSURANCE IN AWARD: dummy variable, 1 if the child support award required health insurance.

DAD INCOME: continuous variable, father's gross annual income at the time of the first action with a child support award (in 1988\$) (from the court record). If missing in the court record, personal taxable income in the calendar year of the award action from the Department of Revenue data (also in 1988\$).

DAD EMPLOYED: dummy variable, 1 if the main source of father's income is employed by other (not self-employed or receiving transfer income) (from the court record).

DAD AGE: continuous variable for the father's age on the date of the paternity or divorce petition.

CHILD AGE: continuous variable for the age of the youngest child on the date of the paternity or divorce petition.

MOM INCOME: continuous variable, mother's annual gross income at the time of the first action with a child support award (in 1988\$) (from the court record). If missing in the court record, personal taxable income in the calendar year of the award action from the Department of Revenue data (also in 1988\$).

MOM AFDC: dummy variable, 1 if the mother received AFDC during the month of the child support action or in any of the previous six months (from an administrative AFDC record).

MILWAUKEE: dummy variable, 1 if the case was decided in Milwaukee.

AWARD 1985: dummy variable, 1 if the case's first child support award was in 1985 (omitted category 1984).

AWARD 1986: dummy variable, 1 if the case's first child support award was in 1986 (omitted category 1984).

AWARD 1987: dummy variable, 1 if the case's first child support award was in 1987 (omitted category 1984).

AWARD 1988-1989: dummy variable, 1 if the case's first child support award was in 1988 or 1989 (omitted category 1984).

The following dummy variables for cases with missing information were also included: MISSING DAD INCOME; MISSING DAD EMPLOYMENT; MISSING MOM INCOME. 


\section{Endnotes}

${ }^{1}$ Many of the fathers were probably already providing insurance before the need to seek a child support order arose (e.g., when they were still married to their spouse) and simply continued to provide coverage after they lost custody of their children.

${ }^{2}$ Although never-married women have become an increasingly larger percentage of women with awards and their rate of insurance coverage is lowest, these facts do not explain the decline. The percentage of ever-married women with child support awards who had coverage dropped from 48 percent in 1983 to 42 percent in 1989, causing the overall decline.

${ }^{3}$ Nightingale et al. (1986) identified families receiving either child support or alimony, and assumed that the number should be discounted by 10 percent to account for children whose noncustodial parent is providing some cash but might not be able to provide insurance coverage. They estimate that fewer than 10 percent of the children in single-parent families receiving Medicaid in 1984 could have conceivably been covered by private insurance. However, as many as 30 percent of the uninsured children in single-parent families perhaps could have been covered by their noncustodial parent's private health insurance.

More recently, the General Accounting Office (1992) provided a simple estimate of the amount of potential savings if children currently covered by Medicaid were instead covered by the private health insurance of their noncustodial father. The GAO calculated this number by examining the records of children receiving Medicaid whose fathers were paying some child support and were also supposed to provide health insurance. They report that only 51.5 percent of these children were actually covered by their fathers' health insurance, and estimate that 81 percent could have been if their fathers had employer-provided coverage to the same extent that all employed fathers had employer-provided coverage. This report did not calculate the potential number of uninsured children who could have been covered.

${ }^{4}$ The 1992 survey for the first time asked questions about the child support of custodial fathers as well as custodial mothers. Results from this survey have not yet been released to analysts. 
${ }^{5}$ The results presented here differ somewhat from the published results because the screening patterns used in the CPS-CSS incorrectly include some women who are no longer demographically eligible for child support (i.e., they no longer have a child under age twenty-one in the home whose other parent is absent). This problem has been noted in other analyses using the CPS-CSS (see, for example, Beller \& Graham, 1993). A screener that attempts to include only those demographically eligible for child support deletes 106 out of 4355 cases; the aggregate numbers do not change a great deal.

${ }^{6}$ Of the women who reported that child support payments had been "agreed to or awarded" and that they had health insurance in their awards, 8 percent also reported that no cash child support was due in 1989. This could be because they had a health insurance award but not a cash award, or it could be a problem with the timing of the question, in which the question relating to cash covers calendar year 1989, but the question about health insurance presumably refers to the award in effect at the time of the survey, April 1990.

${ }^{7}$ Note that the unit of analysis has changed from family to one child per family. The CPS-CSS has information on the health insurance status of each child, but information on child support awards only on each family. I selected the youngest child in each family that was presumably eligible for child support. Remarried women represent cases that cause the most difficulty in moving from a family-based measure to a child-based measure: when the "new" husband was listed as head of the family, I took the youngest stepchild; when the woman was listed as the head of the family, I took the youngest child. It may have been incorrect to do either of these if the youngest child was a child of the current partnership, a situation that could not be distinguished in these data.

${ }^{8}$ For a small number of cases, I did not have a custodial parent's report of health insurance coverage or a noncustodial parent's report. I did, however, know whether the custodial parent was receiving AFDC. If the custodial parent was receiving AFDC, the children would have been covered by Medicaid, and thus would not have been uninsured. I did not, however, know whether they also had private insurance coverage. 
${ }^{9} \mathrm{~A}$ full analysis of those missing information is beyond the scope of this paper. Clearly little can be said about those missing both insurance status and income. But those missing only one can be compared to those with both present to determine the likely direction of bias.

If we combine children who are either uninsured or receive Medicaid only, we know the income and insurance status of 332 noncustodial parents. Of these parents, 56 percent are uninsured. Among the 27 cases with unknown incomes and known insurance status, 82 percent are uninsured, suggesting that those with unknown incomes are indeed disadvantaged.

Of the 332 noncustodial parents with full information, 50 percent have incomes of $\$ 10,000$ or less. Among the 170 parents with unknown insurance status and known incomes, 66 percent have incomes of $\$ 10,000$ or less. This suggests that those with unknown insurance status are also likely to be disadvantaged.

${ }^{10}$ Another possibility is that a custodial parent (or her/his lawyer) who is effective in securing a high award may also be effective in securing health insurance. Similarly, perhaps judges who are more aware of recent child support legislation may order higher cash awards and health insurance.

${ }^{11} \mathrm{~A}$ treatment effects model, following Barnow et al. (1980), was used. The procedure involved three steps. First, an equation estimating the probability of having health insurance in the award was estimated. Second, the results of this equation were used to calculate a term, lambda, which is analogous to the sample selection correction term proposed by Heckman (1979) and others. Finally, the lambda was included in the equation that estimated the effect of insurance on the award amount. 


\section{References}

AARP. 1993. Reforming the Health Care System: State Profiles, 1993. Washington, D.C.: AARP.

Barnow, Burt S., Glen G. Cain, and Arthur S. Goldberger. 1980. "Issues in the Analysis of Selectivity Bias." Evaluation Studies Review Annual 5: 43-59.

Beller, Andrea H. and John W. Graham. 1993. Small Change: The Economics of Child Support. New Haven, Conn.: Yale University Press.

Brown, Pat, Carol L. Roan, and J. Laird Marshall. 1994. "Sample Design, Wisconsin Child Support Demonstration Project." Institute for Research on Poverty, University of Wisconsin-Madison, June 1994.

Goldfarb, Sally F. 1987. "Child Support Guidelines: A Model for Fair Allocation of Child Care, Medical, and Educational Expenses." Family Law Quarterly 21(3): 325-49.

Gordon, Anne R. 1991. "Income Withholding, Medical Support, and Services to Non-AFDC Cases after the Child Support Enforcement Amendments of 1984." Report prepared under contract no. 282-87-1009 for the U.S. Department of Health and Human Services, Office of Child Support Enforcement. Princeton, N.J.: Mathematica Policy Research, Inc.

Heckman, James J. 1979. "Sample Selection Bias as a Specification Error." Econometrica 47(1): 153-61. Kasper, Judith D. 1986. "Health Status and Utilization: Differences by Medicaid Coverage and Income." Health Care Financing Review 7(4): 1-17.

Meyer, Daniel R. 1993. "Supporting Children Born Outside of Marriage: Do Child Support Awards Keep Pace with Changes in Fathers’ Incomes?" Institute for Research on Poverty, Discussion Paper \#102693, University of Wisconsin-Madison.

Moyer, M. Eugene. 1989. "A Revised Look at the Number of Uninsured Americans." Health Affairs 8(2): $102-110$. 
Nightingale, Demetra Smith, Katherine Swartz, Larry Beyna, Sue Poppink, Mary Christman, and Susan Kessler Beck. 1986. "The Inclusion of Medical Coverage in Child Support Cases: Current Status and Options for the Future." Draft. Washington, D.C.: The Urban Institute.

Phillips, Elizabeth and Irwin Garfinkel. 1993. "Income Growth among Nonresident Fathers: Evidence from Wisconsin." Demography 30: 227-41.

Sheils, John F. and Patrice R. Wolfe. 1992. "The Role of Private Health Insurance in Children's Health Care." The Future of Children 2(2): 115-33.

Sonenstein, Freya L. and Charles Calhoun. 1988. "Survey of Absent Parents: Pilot Results." Report prepared under contract HHS-1OO84-0057. Washington, D.C.: U.S. Department of Health and Human Services, Office of the Assistant Secretary for Planning and Evaluation.

U.S. Bureau of the Census. 1986. Current Population Reports, Series P-23, no. 148. Child Support and Alimony: 1983. (Supplemental Report). Washington, D.C.: U.S. Government Printing Office. . 1989. Current Population Reports, Series P-23, no. 154. Child Support and Alimony:

1985. (Supplemental Report). Washington, D.C.: U.S. Government Printing Office. . 1990. Current Population Reports, Series P-23, no. 167. Child Support and Alimony: 1987. Washington, D.C.: U.S. Government Printing Office. . 1991a. Current Population Reports, Series P-60, no. 173. Child Support and Alimony: 1989. Washington, D.C.: U.S. Government Printing Office. . 1991b. Current Population Reports, Series P-60, no. 171. Poverty in the United States: 1988 and 1989. Washington, D.C.: U.S. Government Printing Office. . 1993a. Current Population Reports, Series P-20, no. 468. Marital Status and Living Arrangements: March 1992. Washington, D.C.: U.S. Government Printing Office. 1993b. Current Population Reports, Series P-60, no. 185. Poverty in the United States: 1992.

Washington, D.C.: U.S. Government Printing Office. 
U.S. General Accounting Office. 1992. Medicaid: Ensuring that Noncustodial Parents Provide Health Insurance Can Save Costs. GAO/HRD-92-80. Washington, D.C.: U.S. General Accounting Office. U.S. House of Representatives, Committee on Ways and Means. 1993. Overview of Entitlement Programs: 1993 Green Book. Washington, D.C.: U.S. Government Printing Office.

Wolfe, Barbara L. 1992. "Reform of Health Care for the Poor." Paper presented at "Poverty and Public Policy: What Do We Know? What Should We Do?" conference, Madison, Wis., May 1992. 